\title{
ТВОРЕННЯ ПОЛІТИЧНИХ ТЕРМІНІВ НА ОСНОВІ АНТРОПОНІМІВ УКРАЇНСЬКИХ ПОЛІТИКІВ (на матеріалі публіцистичного дискурсу)
}

\author{
ДОМІНІКА ЯНЧУРА \\ Університет імені Адама Міцкевича, Познань - Польща \\ dominikajanczura@interia.eu; ORCID: 0000-0001-5634-7044
}

\section{TWORZENIE TERMINÓW POLITYCZNYCH NA PODSTAWIE ANTROPONIMÓW UKRAIŃSKICH POLITYKÓW (na materiale dyskursu publicystycznego)}

\author{
DOMINIKA JANCZURA \\ Uniwersytet im. Adama Mickiewicza, Poznań — Polska
}

\begin{abstract}
STRESZCZENIE. Artykuł został poświęcony analizie terminów politycznych derywowanych od antroponimów funkcjonujących w języku dyskursu publicystycznego. Aktualność tematu jest dostrzegalna $\mathrm{w}$ potrzebie ciągłego badania języka mediów masowych — środki komunikacji masowej są aktualizatorami nowych trendów językowych, tym samym sprzyjając wzbogacaniu zasobu leksykalnego użytkowników danego języka. Celem badania jest scharakteryzowanie najbardziej produktywnych modeli słowotwórczych używanych w dyskursie publicystycznym. W artykule został przeanalizowany materiał faktologiczny ze słownika Словотворчість незалежної України 1991-2011 A. Neluby. Materiał badawczy został uzupełniony terminami zebranymi przez autorkę artykułu z wydań elektronicznych prasy ukraińskiej ostatnich lat. Analiza zebranego materiału pozwoliła dojść do wniosku, że najbardziej produktywnymi sposobami tworzenia neologizmów są te, które polegają na dodaniu prefiksu lub sufiksu do wyrazu podstawowego oraz tworzenie złożeń.
\end{abstract}

Słowa kluczowe: termin polityczny, antroponim, media masowe, dyskurs publicystyczny 


\title{
THE FORMATION OF POLITICAL TERMS BASED ON ANTHROPONYMS OF UKRAINIAN POLITICIANS (case study of political discource)
}

\author{
DOMINIKA JANCZURA \\ Adam Mickiewicz University, Poznań — Poland
}

\begin{abstract}
This paper presents the analysis of political terms derived from anthroponyms used in the mass media discourse. The topicality of the paper consists in the need to explore the language of mass media - new linguistic trends are disseminated through mass communication, thus stimulating the development of the vocabulary of users of a given language. The analysis aims at distinguishing and defining the most productive models of word formation used in the mass media discourse. The empirical material examined in the article is based on the dictionary Slovotvorchist nezalezhnoi Ukrainy. 1991-2011 compiled by A. Nelyuba. It was supplemented by terms found by the author of the article in digital issues of the Ukrainian press of recent years. The investigation submitted leads to the conclusion that the most productive models of creating neologisms are adding prefixes or suffixes to root words or compounding.
\end{abstract}

Key words: political term, anthroponym, mass media, journalistic discourse

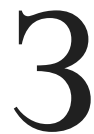

агальновідомо, що арсенал лексичних засобів кожної окремої людини, як і суспільства загалом, постійно поповнюється. Шляхів збагачення мовного словника кожної людини чимало. У час, коли все більшу роль у суспільстві відіграють мас-медіа, саме їх уважають актуалізаторами нових мовних трендів. Здійснений аналіз діапазону впливової сили сучасних мас-медіа дає змогу стверджувати, що вони виконують насамперед лінгвокреативну та внормовувальну функції. Від змісту використаних слів у публіцистичному дискурсі залежить реакція суспільства на події довкілля, формування мовної свідомості особистості. Для громадської думки доречно підбирати лексичний матеріал, моделюючи смисл і прогнозуючи оцінку висловлюваному, передбачаючи можливі емоції.

Лексико-семантичні інновації, зокрема в мові публіцистичного дискурсу, досліджують такі вчені, як напр.: О. Ільченко [2011, 2012], Б. Коваленко [2010], Т. Космеда [2011], О. Мінкова [2012], М. Навальна [2011], А. Нелюба [2012], М. Степаненко [2017], О. Стишов [2013] та ін.

Мова засобів масової інформації еволюціонує разом з розвитком суспільства, віддзеркалює події, що відбуваються у світі. Погоджуємося 3 думкою Т. Щукліної, яка зауважує, що характерною рисою словотворчості в сучасних мас-медіа стало активне залучення до дериваційних процесів різних прецедентних феноменів [Щуклина 2017: 210]. Зазначена дослідниця вважає, 
що „похідні слова, мотивувальною базою яких є прецедентні одиниці, ще більшою мірою відображають специфічність культури, мислення та сприйняття дійсності народу, систему його світоглядних установок, ціннісних пріоритетів. Саме на цьому грунтується спільність для всього народу картини світу й можливість взаєморозуміння" [Щуклина 2017: 210]. Антропоніми політиків функціюють як прецедентні імена, оскільки вони дуже популярні. Не маємо сумнівів, що найбільше емоційних реакцій у суспільстві викликає діяльність політиків, насамперед мовленнєва, їхні комунікативні стратегії й тактики. Мас-медіа - головне джерело знань про політичні події. “Мода” на відантропонімні терміни пов'язана 3 актуальними політичними подіями, активністю певних політиків, їхньою популярністю, рейтингом, авторитетом, а це зумовлює виникнення нових понять і явищ, що мотивовані антропонімами, які номінують прізвища цих політиків. Саме тому зосередимо увагу на політичній терміносистемі. У статті використовуємо терміни мас-медіа й засоби масової інформації (далі ЗМІ) як синонімні.

О. Крижко зауважує, що терміни становлять „більшість нових лексичних одиниць у будь-якій мові [...], оскільки людство постійно зіштовхується 3 проблемою позначення того чи того поняття, явища чи феномена" [Крижко: 62]. Відантропонімні політичні терміни, що функціюють у сучасному українському публіцистичному дискурсі, служать не тільки для найменування нових понять чи явищ, а також для привертання уваги реципієнтів до описуваних фактів, впливу на їхню мовну свідомість. Названі терміни виконують не тільки номінативну функцію, але й низку прагматичних - оцінювальну, експресивну, емоційну, атракційну та ін. На прагматичні функції термінологічних інновацій звертає увагу Т. Щукліна, указуючи на конотаційний компонент новоутворень і називаючи їх яскравими, нестандартними словами, що реалізують творчу компетенцію їхніх творців [Щуклина 2017: 211]. Вони мовні інновації - деавтоматизовують процес іхнього сприйняття читачем, привертають увагу й посилюють вплив мови на підсвідомість адресанта, одночасно спонукаючи його до більш уважного прочитання викладеного [див.: Щуклина 2017: 211]. Усе ж таки головною функцією мас-медіа є формування громадської думки.

Політичні відонімні терміни, що є предметом цієї наукової студії, творяться за вже наявним в українській мові моделями термінотворення. Із часом новоутворені спеціальні одиниці й словосполучення стають загальновживаними, активно функціюють у мові 3МI, що є об'єктом цього дослідження. Термін, зрозуміло, повинен мати точну дефініцію, що „дає загальне уявлення про іменований об'єкт (який може бути як конкретним, так і абстрактним розумовим конструктом) [...]" [Крижко: 62-63]. На відміну від загальновживаних слів, терміни, як правило, однозначні. Терміни належать не до загальновживаної, а до спеціальної лексики, оскільки вони існують у науковій мові 
[Кочан 2018: 54]. Однак зауважмо, що терміноодиниці мови публіцистики можуть використовуватися в повсякденному мовленні, проникаючи до системи загальної мови й поповнюючи тим самим словник суспільства загалом. Погоджуємося 3 думкою Н. Поліщук про те, що „поява лексичної чи семантичної інновації завжди чимось зумовлена" [Поліщук 2016: 147]. Політичні відантропонімні новотвори тісно пов'язані з актуальною політичною ситуацією. Без сумніву, деякі з політичних відантропонімних термінів віддзеркалюють ставлення суспільства до конкретних політиків.

Як джерело для вибирання політичних відантропонімних термінів використано словник А. Нелюби Словотворчість незалежної України. 1991-2011 [Нелюба 2012]. Дослідницький матеріал доповнено прикладами, зібраними авторкою цієї статті з українських газет 2004-2018 pp.

Наголосімо, що термінологічні системи розбудовуються трьома основними способами: 1) морфологічним (афіксальним) - утворенням нових термінологічних найменувань за певними словотвірними моделями; 2) лексико-семантичним, що передбачає термінологізування значень слів природної мови, та ін.; 3) через запозичення (словотвірне та семантичне калькування) [Крижко: 65].

Найбільш продуктивним способом творення термінів, зокрема й політичних терміноодиниць на базі антропонімів українських політиків, традиційно вважають морфологічний. Як зауважує Т. Петрова, „поширеність цього способу пояснюють його продуктивністю, оскільки в термінах, утворених морфологічним способом, закладені основи структурного систематизування [...]" [Петрова 2018: 122]. У мові ЗМІ відантропонімні політичні терміни, що виникли шляхом морфологічного термінотворення, переважно утворені суфіксальним і префіксальним способами, а також складанням.

Суфіксальний спосіб творення термінів - це, як відомо, моделювання термінів з використанням суфіксальних морфем. Перший з ефективних прийомів, уживаних журналістами, - творення іменників із суфіксами -ець, -енко, -еня, -ев'я, -ист, -іст, -івець, -нів, -чик, що вказують на послідовників чи прихильників конкретного політичного лідера або членів певного угрупування: ющенківець, граченя, лукашист, луценківець, кравчукіст, литвинівка, жсириновчик. Порівн.: Люди ї “сприйняли серием і розумом” - так брехав міністр АПК, вірний “кучмівець”, згодом “білосердечний антикучмівеиь” як i всі перекинчики, щуо під різними гаслами і прапорами догоджають колонізаторам Украӥни [Мороз 2013]; На дану посаду нібито проситься "ющенківещь” Віктор Бондар, однак проти його кандидатури є серйозний опір [Писарчук 2014]; Головний “тимошенківещь” Деревляний вляпався у любовний скандал "на стороні" $і$ бажає відбити нову пасію Кайди? [Головний “тимошенківець” 2018]; ,,Як путінці, вирішили пограти м'язами” — організатор 
“ностальгічного шабашу” про скандал у Луцьку [Як путінці 2017]; Путіністи рясах. На краю иерковного “вулкану” [Косвінцев 2015].

Для номінування періоду правління чи пов'язаних із конкретним політиком суспільно-політичних явищ зазвичай використовують суфікс -щин(а). Такі номінації репрезентують негативну оцінку: азаровщиина, геббелівщина, морозівщина, хижняківщина, шелестщина, шиаровщина, ющенківщина, яворівщина, януковщина. Порівн.: Але цъього разу це не була проста цікавість, мовляв, що ж там за парканом, це був суспільний ритуал, коли важливо на рівні рефлексів відкласти - “януковщина" повторитися не має [Гладка 2014]; Заява про відставку. ,Азаровщина - ие повне нехтування законом [...]” [Богославская 2004]; Так ие ж кучмівщина в чистому вигляді! [Ротай 2006].

Для моделювання таких образних, промовистих термінів у мові 3МІ за аналогією до утворень на зразок комунізм, більшовизм, фашизм використовують також суфікси -ізм, -изм, що навантажені негативним значенням, порівн.: кравчукізм, кучмізм (Хіба не комсомол виховав кравчукізм-кучмізм, злодіїв більшого і меншого масштабу? [Сверстюк 2015]), лукашизм (Експорт лукашизму [Кабачій 2013]), януковичізм (Зважаючи на реакцію Івана Марчука, можна припустити, що Україну залишить кагорта тих, комуянуковичізм, як іколись кучмізм, стане нестерпним [Samborska 2010]), путінізм (Путінізм завжди пожирає своїх дітей [Волошина 2016]), бандеризм (Бандеризм, якого немає [Кіпіані 2018]).

На позначення нових процесів, запропонованих конкретним політичним діячем, використовують чужомовний суфікс -ij- (аналогічно, напр., до словесних форм на зразок приватизація), порівн.: кіселізація (Сьогодні відомий вислів Леніна міг би звучати так: „, Україна - ие Партія регіонів плюс шустеризація і кіселізація всієї краӥни” [Нелюба 2012: 219]), путінізація (Одним з найбільш гострих і актуальних питань на сьогодні є: чи мож-лива остаточна "путінізація" України? [Жданов 2010]), тимошенкізація ("Тимошенкізація" євроінтеграції [Гетьманчук 2012]), ющенкізація (Я изе називаю “ющенкізація" партійного списку “Удару”, —зазначив він [Кличко, Королевська 2012]). Утім нормативним суфіксом для творення українських термінологічних найменувань (а також на основі чужомовних морфів, що давно запозичені) на позначення дії чи процесу є -енн(я), -нн(я).

Знаходимо також поодинокі приклади з актуалізацією суфікса -іан(а), що ïx використовують на позначення заходів, присвячених ушануванню пам'яті конкретного політика, напр., брежнєвіана, ющенкіана, януковичіана. Порівн.: Готуючись до вщанування пам'яті Леоніда Ілліча з нагоди його 100-річного ювілею, можновладиі Дніпродзержинська обговорювали ідею присвоєння імені видатного земляка якійсь вулииі або місиевому парку відпочинку. Отож “брежнсвіана” триває? [Нелюба 2012: 60]. Зауважмо, що вказаний суфікс 
частіше використовують для моделювання термінів 3 актуалізуванням прізвищ письменників. Такі утворення позначають сукупність творів літератури й мистецтва, пов'язаних із життям конкретного творця.

У публіцистиці популярним способом термінотворення $є$ префіксальний. Для побудови термінів, зміст дефініції яких містить указівку на ознаку за віднесеністю до того, хто виступає проти конкретного політика, часто використовують префікс анти-, напр.: антиграбовичівський, антилуценківський, антитабачний, антитимотенківський, антихусейнівський, античерновецький, антиющенківський, антияворівський, антияценюківський. Порівн.: Переважають викиди антиграбовичівської публіцистики, на яку адепти Грабовича не знайшли адекватної відповіді [Нелюба 2012: 25]; Натомість мітинг, який міська влада дозволила “антилуценківським” партіям (ПР, СПУ, КПУ, зеленим) провести на майдані Свободи, виявився набагато гучнішим [Нелюба 2012: 27]; “АнтиТабачний” ректор могилянки Сергій Квіт: не в ногу з усіма [Охріменко 2010]. В останньому прикладі в середині слова використано прийом капіталізації, тобто вжито велику літеру, що суперечить правилам української орфографії.

Префікс анти- функціює також як компонент побудови іменників, що, відповідно, номінують супротивників конкретного політика, порівн.: Потім як антикуцмовець; трансформер-соціаліст; “польовий командир” Майдану; “термінатор" - винищувач корупиіонерів і ДАЇ [...] [Нелюба 2012: 27]; I да, зараз почнуться змагання, хто більший антипутінець, але подивіться правdi в очi [Iesipov 2018]. Зауважмо, що в наведених прикладах префікс антинавантажений негативним змістом: він, як правило, означає протилежність, протидію, набуває відтінку несхвалення, зневажливості.

Інколи в словотворенні журналісти використовують питомий (український) відповідник префікса анти- — проти-, порівн.: Протибагрянівська преса, зокрема часопис “Украйнський самостійник”, звинувачували Івана Багряного у "політичному диктаторстві і вождівстві", "крутійстві та неокомуністичній поведіниі" [Нелюба 2012: 438-439]; Водночас заради справедливості зауважу, що Словенія, на відміну, скажімо, від Сербї, у різних міжнародних організаціях завжди голосує за проукраїнські, відповідно протипутінські - рімення [Ільченко 2018].

Префіксальний спосіб термінотворення в публіцистичному мовленні використовує також афікс де-, напр.: декучмізаиія, депутінізаиія, деющенкізаиія. Порівн.: Плюс декучмізація всієї краӥни [Захаров 2005]; РФ потребує двох речей: декомунізаиії і депутінізації - російський політолог Андрій Зубов [Горчинська 2017]; Йдеться якщо не про витіснення Ющенка Пінчуком з иього міжнародного каналу, то принаймні про демонополізачію контактів, або про деющенкізацію позаурядової дипломатії [Нелюба 2012: 123]. Указані терміни називають процес, спрямований на позбавлення ознак, характерних 
для конкретного політика. Зауважмо, що префікси, використовувані для моделювання журналістами термінів, відповідно навантажені негативним значенням, що свідчить про перевагу негативних емоцій щодо оцінки дій політиків.

Від антропонімів шляхом складання, утворюються й складні терміноодиниці 3МІ, напр.: бандерофобія (Бандерофобія в російській пропаганді: історія і сучасність [Масенко 2016]), тимошенкофобія (Пароксизми тимошенкофобії [Шевченко 2016]). Такі номінації слугують для позначення ірраціонального сприйняття (фобіi), потенційної загрози.

Для окреслення типу “правління” певного політичного лідера чи групи моделюють складні слова з використанням основи -кратія в постпозиції, що в перекладі з грецької мови означає 'правити, володіти; бути сильним' (напр.: демократія, бюрократія), порівн.: тітушкократія (Час тітушкократії [Канєвський 2018]), кучмократія (І запланована зміна державного ладу - ие не щзо інше, як державний переворот, щзо його має намір здійснити кучмократія, прикриваючись гаслами конституційної реформи [Каспрук 2013]).

Отже, терміносистему сучасних мас-медіа більшою мірою наповнюють новоутворені політичні терміни на позначення прихильників конкретного політика чи членів політичного угрупування. Значна кількість терміноодиниць окреслює період правління конкретного політика й започатковані ним політичні зміни. Чимало спеціальних одиниць указують на ознаку за належністю до того, хто виступає проти конкретного політика.

Найбільш популярними способами термінотворення одиниць мас-медіа $\epsilon$, як показує проаналізований матеріал, суфіксальний і префіксальний. Найбільш продуктивними формантами, що актуалізуються під час творення відантропонімних термінів суфіксальним способом, є афікси -ець (для позначення прихильників, послідовників конкретного політика) та -щина (для номінування періоду правління, явищ, пов’язаних з певним політиком). Префіксальним способом завдяки продуктивним афіксам анти-, проти- та де- утворюють численну групу термінів, дефініції яких містять указівку на ознаку за віднесеністю до того, хто виступає проти конкретного політика. Для творення оцінних політичних номінацій залучають і спосіб складання, за допомогою якого моделюються значення з місткими смислами.

Отже, більшість новоутворених політичних термінів, проаналізованих у мові 3МІ, віддзеркалюють суспільно-політичну дійсність, почуття й емоції соціуму. Діапазон впливу мас-медіа створює можливості поширення нової лексики серед суспільства, тим самим поповнюючи лексичний склад української мови. Убачаємо потребу постійного відстеження виникнення мовних новоутворень у мові 3МІ та їхнього лексикографування, оскільки вони поширюються в публіцистичному дискурсі дуже швидко й набувають статусу загальновживаних. 


\section{Список використаної літератури}

Ільченко О. А., Вербалізоване “обличчя” сучасного суспільства: словник метафоричних словосполучень української преси (2000-2010рр.), Харків: ФОП Петров В.В., 2011.

Ільченко О. А., Прецедентність як ознака текстів сучасної преси (на матеріалі метафоричних словосполучень), [в:] „Лінгвістичні дослідження”, 2012, вип. 34, c. $97-100$.

Коваленко Б. О., Стилістично знижена лексика в мові сучасної украӥнської публіцистики, Кам'янець-Подільський: Буйницький О. А., 2010.

Космеда Т. А., Мова “четвертої влади” та шляхи ї̈ вдосконалення: компетенція мовної особистості журналіста і читача, [в:] „Ученые записки Таврического национального университета им. В. И. Вернадского. Серия «Филология. Социальные коммуникации»”, 2011, № 4, т. 24 (63), с. 157-162.

Кочан I., Слова з терміноелементами -граф(о), -граф, -граф(ія), -граф(ізм) у сучасній українській мові, [в:] „Studia Ukrainica Posnaniensia”, 2018, zesz. VI, s. 53-60.

Крижко О. А., Особливості терміна як основної одиниці терміносистеми, [в:] Електронний pecypc: http://philology.knu.ua/library/zagal/Studia_Linguistica_1/062_067.pdf (12.09.2017).

Мінкова О. Ф., Експресивний потенціал засобів вторинної номінації в мові новітньої української публіцистики, Мелітополь: ТОВ „Видавничий будинок ММД”, 2012.

Навальна М. І., Динаміка лексикону української періодики початку XXI cm., Київ: Вид. дім Дмитра Бураго, 2011.

Петрова Т., Морфологічні способи термінотворення (на матеріалі сучасної украӥнської фітомеліоративної термінологіï), [в:] „Studia Ukrainica Posnaniensia”, 2018, zesz. VI, s. $121-129$.

Поліщук Н., Активність інноваційних процесів у словниковому складі сучасних масмедіa, [в:] „Вісник Національного університету «Львівська політехніка»”, 2016, № 842 , с. $146-150$.

Ротко С. І., Дефініиії понять термінологія та терміносистема у сучасній лінгвістииі, [в:] „Науковий часопис НПУ імені М. П. Драгоманова. Серія 9: Сучасні тенденції розвитку мов”, 2013, вип. 10, с. 234-239.

Степаненко М. І., Політичне сьогодення української мови: актуальний перефрастикон, Харків: Видавець Іванченко І. С., 2017.

Стишов О., Українська лексика кіния ХХ століття (на матеріалі мови засобів масової інформачії), Київ: Вид. центр КНЛУ, 2-ге вид., перероб, 2003.

Щуклина Т., Прещедентные феномены как источник неузуального словообразования в современных российских СМИ, [в:] „Przegląd Wschodnioeuropejski”, 2017, VIII/1, s. 209-217.

\section{Spysok vykorystanoi literatury [References]}

Ilchenko O. A., Verbalizovane "oblychchia” suchasnoho suspilstva: slovnyk metaforychnykh slovospoluchen ukrainskoi presy (2000-2010 rr.) [Verbalized "Face" of Modern Society: 
Dictionary of Metaphorical Phrases of the Ukrainian Press], Kharkiv: FOP Petrov V. V., 2011.

Ilchenko O. A., Pretsedentnist yak oznaka tekstiv suchasnoi presy (na materiali metaforychnykh slovospoluchen) [Precedence as a Feature of the Texts of Modern Press (Based on Metaphorical Phrases], [v:] „Linhvistychni doslidzhennia”, 2012, vyp. 34, s. 97-100.

Kovalenko B. O., Stylistychno znyzhena leksyka v movi suchasnoi ukrainskoi publitsystyky [Stylistically Reduced Vocabulary in the Language of Modern Ukrainian Journalism], Kamianets-Podilskyi: Buinytskyi O.A., 2010.

Kosmeda T. A., Mova "chetvertoi vlady" ta shliakhy yii vdoskonalennia: kompetentsiia movnoi osobystosti zhurnalista i chytacha [The Language of the "Fourth Power" and the Ways of Its Perfection: the Competence of the Linguistic Personality of the Journalist and the Reader], [v:] „Uchenye zapiski Tavricheskogo nacionalnogo universiteta im. V. I. Vernadskogo. Seriya «Fylologiya. Social'nye kommunikacii»", tom 24 (63), 2011, № 4, s. 157-162.

Kochan I., Slova $z$ terminoelementamy -hraf(o), -hraf, -hraf(iia), -hraf(izm) u suchasnii ukrainskii movi [Words with Term Elements граф(o), -граф, -граф(ія), -граф(ізм) in Modern Ukrainian], [v:] „Studia Ukrainica Posnaniensia”, 2018, zesz. VI, s. 53-60.

Kryzhko O. A., Osoblyvosti termina yak osnovnoi odynytsi terminosystemy [Features of the Term as the Basic Unit of the Terminology System], [v:] Elektronyi resurs: http://philology. knu.ua/library/zagal/Studia_Linguistica_1/062_067.pdf (12.09.2017).

Minkova O. F., Ekspresyvnyi potentsial zasobiv vtorynnoi nominatsii v movi novitnoi ukrainskoi publitsystyky [Expressive Potential of Means of Secondary Nomination in the Language of Modern Ukrainian Journalism], Melitopol: TOV „Vydavnychyi budynok MMD”, 2012.

Navalna M. I., Dynamika leksykonu ukrainskoi periodyky pochatku XXI st. [The Dynamics of the Lexicon of the Ukrainian Periodicals at the Beginning of the XXI Century], Kyiv: Vyd. dim Dmytra Buraho, 2011.

Neliuba A., Slovotvorchist nezalezhnoi Ukrainy. 1991-2011 [Word-Formation in Independent Ukraine. 1991-2011], Kharkiv 2012.

Petrova T., Morfolohichni sposoby terminotvorennia (na materiali suchasnoi ukrainskoi fitomelioratyvnoi terminolohii [Morphological Methods of Term Formation (on the Material of Modern Ukrainian Phytomeliorative Terminology)], [v:] „Studia Ukrainica Posnaniensia”, 2018, zesz. VI, s. 121-129.

Polishchuk N., Aktyvnist innovatsiinykh protsesiv u slovnykovomu skladi suchasnykh mas media [The Activity of Innovative Processes in the Vocabulary of Modern Mass Media], [v:] „Visnyk Natsionalnoho universytetu «Lvivska politekhnika»”, 2016, № 842, s. 146-150.

Rotko S. I., Definitsii poniat terminolohiia ta terminosystema u suchasnii linhvistytsi [Definition of the Concepts of Terminology and Terminology System in Modern Linguistics], [v:] „Naukovyi chasopys NPU imeni M. P. Drahomanova. Seriia 9: Suchasni tendentsii rozvytku mov", 2013, vyp. 10, s. 234-239.

Stepanenko M. I., Politychne sohodennia ukrainskoi movy: aktualnyi perefrastykon [The Political Present of the Ukrainian Language: an Actual Rephrasicon], Kharkiv: Vydavets Ivanchenko I. S., 2017. 
Styshov O., Ukrainska leksyka kintsia XX stolittia (na materiali movy zasobiv masovoi informatsii) [Ukrainian Vocabulary of the Late Twentieth Century (Based on the Language of the Mass Media)], Kyiv: Vyd. tsentr KNLU, 2-he vyd., pererob, 2003.

Shchuklina T., Precedentnye fenomeny kak istochnik neuzual'nogo slovoobrazovaniya $v$ sovremennyx rossijskix SMI [Precedent Phenomena as the Source of Non-Usual WordFormation in the Contemporary Russian Mass Media], [v:] „Przegląd Wschodnioeuropejski”, 2017, VIII/1, s. 209-217.

\section{Список використаних джерел}

Богословская И., Заява про відставку. „Азаровщина - ие повне нехтування законом... ”, [в:] Електронний pecypc: https://www.pravda.com.ua/news/2004/01/19/2997554/ (19.01.2004).

Волошина Л., Путінізм завжди пожирає своїх дітей, [в:] Електронний ресурс: https:// gazeta.ua/blog/49125/putinizm-zavzhdi-pozhiraye-svoyih-ditej (06.08.2016).

Гетьманчук А., Пилявець О., Солодкий С., Три сиенарії розвитку відносин Україна - $С С$ після виборів-2012, [в:] Електронний ресурс: https://glavcom.ua/publications/118979-tristsenariji-rozvitku-vidnosin-ukrajina-jes-pislja-viboriv-2012.html (22.10.2012).

Гладка К., Ритуал “Межигір'я”, [в:] Електронний ресурс: http://life.pravda.com.ua/ columns/2014/02/25/153939/ (25.02.2014).

Головний “тимошенківець”" Деревляний вляпався у любовний скандал "на стороні” $i$ бажає відбити нову пасію Кайди?, [в:] Електронний ресурс: http://chasopys.te.ua/ suspilstvo/5099-golovnij-timoshenkivets-derevlyanij-vlyapavsya-u-lyubovnij-skandal-nastoroni-i-bazhae-vidbiti-novu-pasiyu-kajdi (06.04.2018).

Горчинська О., РФ потребує двох речей: декомунізачії $і$ депутінізацї - російський політолог Андрій Зубов, [в:] Електронний ресурс: https://nv.ua/ukr/publications/rfmaje-potrebu-v-dvoh-rechah-dekomunizatsiji-i-deputinizatsii-rosijskij-politolog-andrijzubiv-966656.html (12.04.2017).

Жданов I., Чи можслива “путінізація” України?, [в:] Електронний ресурс: https://www. pravda.com.ua/articles/2010/10/7/5454113/view_print/ (07.10.2010).

Захаров Є., Плюс декучмізація всієї країни, [в:] Електронний ресурс: http://maidan.org.ua/ $\operatorname{arch} / \operatorname{arch} 2005 / 1104949600 . h t m l(01.05 .2005)$.

Ільченко В., Словенія. Найбагатша у слов'янському світі, [в:] Електронний ресурс: http:// www.mandry.ua/?p=3728, (31.01.2018).

Кабачій Р., Експорт лукашизму, [в:] Електронний ресурс: https://www.pravda.com.ua/ columns/2013/03/8/6985139/ (08.03.2013).

Канєвський Г., Час тітушкократії, [в:] Електронний ресурс: https://www.pravda.com.ua/ columns/2018/02/19/7172066/ (19.02.2018).

Каспрук В., Кучма здає Украӥну, [в:] Електронний ресурс: https://viktorkaspruk.wordpress. com/2013/05/10/кучма-здає-україну/ (10.05.2013).

Кіпіані В., Бандеризм, якого немає, [в:] Електронний ресурс: https://nv.ua/ukr/opinion/ kipiani/banderizm-jakoho-nemaje-2453817.html (24.02.2018). 
Кличко і Королевська мають пули спонсорів, —політолог, [в:] Електронний ресурс: https:// galinfo.com.ua/news/klychko_i_korolevska_mayut_puly_sponsoriv_politolog_115407. html (04.08.2012).

Косвінцев О., Путіністи в рясах. На краю церковного “вулкану”, [в:] Електронний ресурс: https://zaxid.net/putinisti_v_ryasah_n1376501 (15.12.2015).

Масенко Л., Бандерофобія в російській пропаганді: історія і сучасність, [в:] Електронний pecypc: https://www.radiosvoboda.org/a/28206392.html (31.12.2016).

Мороз О., Про найважливішу справу, [в:] Електронний ресурс: http://www.spu.pl.ua/post. php?id=11923 (05.09.2013).

Нелюба А., Словотворчість незалежної Украӥни 1991-2011: Словник, Харків: Харків. історико-філол. тов-во, 2012.

Охріменко О., “АнтиТабачний” ректор могилянки Сергій Квіт: не в ноги з усіма, [в:] Електронний ресурс: https://www.unian.ua/society/341723-antitabachniy-rektor-mogilyankisergiy-kvit-ne-v-nogu-z-usima.html (30.03.2010).

Писарчук Д., Новий склад Кабміну. Попередній список, [в:] Електронний ресурс: https:// espreso.tv/article/2014/11/12/novyy_sklad_kabminu_poperedniy_spysok (12.11.2014).

Портников В., Віталій Портников: російські “тітушки” - новий символ влади, [в:] Електронний ресурс: https://espreso.tv/article/2018/05/07/vitaliy_portnykov_rosiyski_ quottitushkyquot_novyy_symvol_vlady (07.05.2018).

Ротай Н., “Нафтусина” біда, [в:] Електронний ресурс: http://www.umoloda.kiev.ua/ number/639/247/23161/ (23.03.2006).

Самборська О., „Він шкодує, щуо повернувся з еміграції і готується виїхати знову”, [в:] Електронний ресурс: https://ukrajinciberlinu.wordpress.com/2010/02/22/він-шко-дуєщо-повернувся-з-еміграції-і/ (22.02.2010).

Сверстюк Є., “Багато страшних видінь майбутнього втілив Гоголь у своїх образах, щзо простуватим читачем сприймалися як дивацтво”, [в:] Електронний ресурс: https:// ukrajinciberlinu.wordpress.com/2009/04/01/багато-страшних-видінь-майбутнього-в/ (21.12. 2015).

Шевченко О., Пароксизм тимошенкофобіi, [в:] Електронний ресурс: http://turka-ua.net/ news/2016-01-14-2583 (14.01.2016).

„Як путінці вирішили пограти м'язами” - організатор „ностальгічного шабашу” про скандал у Луцьку, [в:] Електронний ресурс: https://www.volyn24.com/news/94255-iakputinci-vyrishyly-pograty-miazamy-organizator-nostalgichnogo-shabashu-pro-skandal-ulucku (26.11.2017).

Iesipov S., Насправді президентську кампанію можна закінчувати, [в:] Електронний pecypc: https://tverezo.info/post/74409 (19.10.2018).

\section{Spysok vykorystanykh dzherel [References]}

Bohoslovskaia Y., Zaiava pro vidstavku. „Azarovshchyna — tse povne nekhtuvannia zakonom ...” [Resignation Letter. „Azarovshchyna (the Attack of Azarov on Small Business of Ukraine) 
is a Complete Violation of Law], [v:] Elektronnyi resurs: https://www.pravda.com.ua/ news/2004/01/19/2997554/ (ponedilok, 19 sichnia 2004, 18:39).

Voloshyna L., Putinizm zavzhdy pozhyraie svoikh ditei [Putinism Always Devours Its Children], [v:] Elektronnyi resurs: https://gazeta.ua/blog/49125/putinizm-zavzhdi-pozhiraye-svoyihditej (06.08.2016).

Hetmanchuk A., Pyliavets O., Solodkyi S., Try stsenarii rozvytku vidnosyn Ukraina YeS pislia vyboriv 2012 [Three Scenarios for the Development of Ukraine-EU Relations after the 2012 Election], [v:] Elektronnyi resurs: https://glavcom.ua/publications/118979-tri-stsenarijirozvitku-vidnosin-ukrajina-jes-pislja-viboriv-2012.html (22.10.2012).

Hladka K., Rytual "Mezhyhiria" ["Mezhyhiria” Ritual], [v:] Elektronnyi resurs: http://life. pravda.com.ua/columns/2014/02/25/153939/ (25.02.2014).

Holovnyi "tymoshenkivets" Derevlianyi vliapavsia u liubovnyi skandal "na storoni" $i$ bazhaie vidbyty novu pasiiu Kaidy? [The Main Tymoshenko's Ally Derevlianyi Involved in the Scandal Playing Around and Willing to Swipe the Beloved of Kaida], [v:] Elektronnyi resurs: http://chasopys.te.ua/ suspilstvo/5099- golovnij- timoshenkivets- derevlyanij-vlyapavsyau-lyubovnij-skandal-na-storoni-i-bazhae-vidbiti-novu-pasiyu-kajdi (06.04.2018).

Horchynska O., RF potrebuie dvokh rechei: dekomunizatsii i deputinizatsii - rosiiskyi politoloh Andrii Zubov [Russia Needs Two Things: Decommunization and Deputinization, Says Russian Political Scientist Andrii Zubov], [v:] Elektronnyi resurs: https://nv.ua/ukr/publications/ rf-maje-potrebu-v-dvoh-rechah-dekomunizatsiji-ideputinizatsii-rosijskij-politolog-andrij- zubiv-966656.html (12.04.2017).

Zhdanov I., Chy mozhlyva “putinizatsiia” Ukrainy? [Is it Possible to „Putinize” Ukraine?], [v:] Elektronnyi resurs: https:/www.pravda.com.ua/articles/2010/10/7/5454113/view_print/ (07.10.2010).

Zakharov Ye., Plius dekuchmizatsiia vsiiei krainy [Plus Dekuchmization of the Whole Country], [v:] Elektronnyi resurs: http://maidan.org.ua/arch/arch2005/1104949600.html (01.05.2005).

Ilchenko V., Sloveniia. Naibahatsha u slovianskomu sviti [Slovenia: the Richest in the Slavic World], [v:] Elektronnyi resurs: http://www.mandry.ua/?p=3728 (31.01.2018).

Kabachii R., Eksport lukashyzmu [Export of Lukashism], [v:] Elektronnyi resurs: https://www. pravda.com.ua/columns/2013/03/8/6985139/ (08.03.2013).

Kanievskyi H., Chas titushkokratii [The Time of Titushkocracy], [v:] Elektronnyi resurs: https:// www.pravda.com.ua/columns/2018/02/19/7172066/ (19.02.2018).

Kaspruk V., Kuchma zdaie Ukrainu [Kuchma Gives Ukraine Away], [v:] Elektronnyi resurs: https://viktorkaspruk.wordpress.com/2013/05/10/kuchma-zdaie-ukrainu/ (10.05.2013).

Kipiani V.,Banderyzm, yakohonemaie [Banderism, which doesn 'tExist], [v:] Elektronnyi resurs: https://nv.ua/ukr/opinion/kipiani/banderizm-jakoho-nemaje-2453817.html (24.02.2018).

Klychko i Korolevska maiut puly sponsoriv, — politoloh [Klychko i Korolevska have many Sponsors, Claims a Political Expert], [v:] Elektronnyi resurs: https:/galinfo.com.ua/news/ klychko_i_korolevska_mayut_puly_sponsoriv_politolog_115407.html (04.08.2012).

Kosvintsev O., Putinisty v riasakh. Na kraiu tserkovnoho "vulkanu" [Putinists in Cassocks. On the Edge of the Church "Volcano”], [v:] Elektronnyi resurs: https://zaxid.net/putinisti_v_ ryasah_n1376501 (15.12.2015). 
Masenko L., Banderofobiia v rosiiskii propahandi: istoriia $i$ suchasnist [Banderophobia in the Russian Propaganda: the Past and the Present], [v:] Elektronnyi resurs: https://www. radiosvoboda.org/a/28206392.html (31.12.2016).

Moroz O., Pro naivazhlyvishu spravu [On the Most Complicated], [v:] Elektronnyi resurs: http:// www.spu.pl.ua/post.php?id=11923 (05.09.2013).

Neliuba A., Slovotvorchist nezalezhnoi Ukrainy 1991-2011: Slovnyk [Word Formation of Independent Ukraine in 1991-2011: a Dictionary], Kharkiv: Kharkiv. istoryko-filol. tovvo, 2012.

Okhrimenko O., "AntyTabachnyi" rektor mohylianky Serhii Kvit: ne v nohy z usima [,AntiTabachnyk” Rector of the Mohyla Academy Serhii Kvit: Out of Syne], [v:] Elektronnyi resurs: https://www.unian.ua/society/341723-antitabachniy-rektor-mogilyanki-sergiy-kvit-ne-vnogu-z-usima.html (30.03.2010).

Pysarchuk D., Novyi sklad Kabminu. Poperednii spysok [New Members of the Cabinet. The Preliminary List], [v:] Elektronnyi resurs: https://espreso.tv/article/2014/11/12/novyy_sklad_ kabminu_poperedniy_spysok (12.11.2014).

Portnykov V., Vitalii Portnykov: rosiiski "titushky" — novyi symvol vlady [Vitalii Portnikov: Russian "Titushkas" as a New Symbol of Power], [v:] Elektronnyi resurs: https://espreso. tv/article/2018/05/07/vitaliy_portnykov_rosiyski_quottitushkyquot_novyy_symvol_vlady (07.05.2018).

Rotai N., "Naftusyna” bida ["Naftusyniia”"S Misfortune], [v:] Elektronnyi resurs: http://www. umoloda.kiev.ua/number/639/247/23161/ (23.03.2006).

Samborska O., ,,Vin shkoduie, shcho povernuvsia z emihratsii i hotuietsia vyikhaty znovu” [He Regrets Returning from Emigration and is Ready to Leave the Country Again], [v:] Elektronnyi resurs: https:/ukrajinciberlinu.wordpress.com/2010/02/22/vin-shkoduieshcho-povernuvsia-z-emihratsii-i/, (22.02.2010).

Sverstiuk Ie., "Bahato strashnykh vydin maibutnoho vtilyv Hohol u svoikh obrazakh, shcho prostuvatym chytachem spryimalysia yak dyvatstvo" ["Gogol's Terrible Visions of the Future Perceived as Oddity by Average Readers"], [v:] Elektronnyi resurs: https://ukrajinciberlinu. Wordpress.com/2009/04/01/bahato-strashnykh-vydinmaibutnoho-v/ (21.12. 2015).

Shevchenko O.,Paroksyzm tymoshenkofobii [Paroxysm of Tymoshenkophobia],[v:] Elektronnyi resurs: http://turka-ua.net/news/2016-01-14-2583 (14.01.2016).

„Yak putintsi, vyrishyly pohraty miazamy” - orhanizator ,nostalhichnoho shabashu” pro skandal u Lutsku [,, How Putinists Decided to PlayMuscles», the Organizer of ,, the Nostalgic Sabbath'Tells about the Scandal in Lutsk], [v:] Elektronnyi resurs: https://www.volyn24. com/news/94255-iak-putinci-vyrishyly-pograty-miazamy-organizator-nostalgichnogoshabashu-pro-skandal-u-lucku (26.11. 2017).

Iesipov S., Naspravdi prezydentsku kampaniiu mozhna zakinchuvaty [In Fact, the Presidential Campaign can be Finished], [v:] Elektronnyi resurs: https://tverezo.info/post/74409 (19.10.2018). 